\author{
Grażyna Voss \\ Toruński Ośrodek \\ Doradztwa Metodycznego i Doskonalenia Nauczycieli
}

\title{
Zestawienie zmian w skonsolidowanym kapitale własnym
}

Zmiany warunków otoczenia, w których żyjemy, przynoszą codziennie ogromne ilości informacji. Ich użyteczność dla podmiotów gospodarczych jest bardzo zróżnicowana i zależy od wielu czynników. Terminowo dostarczana oraz rzetelna i kompletna informacja może być cennym elementem podejmowania decyzji ekonomicznych przez wszystkich zainteresowanych. Aby tak się stało, użytkownicy tych informacji muszą umieć prawidłowo odczytać i zinterpretować uzyskane wiadomości.

9 listopada 2000 r. uchwalona została ustawa o zmianie ustawy o rachunkowości (Dz.U. Nr 113, poz. 1186), która wprowadziła nowy element sprawozdania finansowego - zestawienie zmian w kapitale (funduszu) własnym. Pozwoli ono na odzwierciedlenie sytuacji majątkowej podmiotu gospodarczego i uzyskanie nowych informacji dotyczących dynamiki zmian w kapitałach własnych wykorzystywanych w zarządzaniu jednostką, a także przez użytkowników zewnętrznych. Dane zawarte w tym zestawieniu pozwolą określić rolę kapitału własnego w samofinansowaniu działalności przedsiębiorstwa oraz rentowność zainwestowanych kapitałów.

Skonsolidowane sprawozdanie sporządza jednostka dominująca, na podstawie sprawozdań poszczególnych jednostek należących do grupy kapitałowej. Zasady sporządzania sprawozdań są podobne jak w wypadku sporządzania sprawozdania finansowego dla indywidualnej jednostki. Sprawozdania finansowe koncentrują się przede wszystkim na rezultatach podjętych wcześniej decyzji. Badanie zmian w kapitale własnym na początek i koniec okresu obrachunkowego pozwala na oszacowanie przyrostu lub spadku aktywów netto jednostki, jej zasobności w ciagu roku. Ogólna zmiana stanu kapitału odpowiada łącznym stratom i zyskom wygenerowanym w wyniku działalności gospodarczej. Zestawienie zmian w kapitale własnym jest niezbędnym elementem sprawozdania finansowego, jednak dopiero przyszłość pokaże, w jakim stopniu zawarte w nim informacje będą wykorzystywane przez poszczególne grupy użytkowników.

Konsolidowanie sprawozdań finansowych jest procesem złożonym, szczególnie na gruncie polskim. Na jego złożoność wpływa stosunkowo krótki okres praktycznych zastosowań procedur konsolidacyjnych oraz niedostrzeganie znaczenia i możliwości wykorzystania skonsolidowanych sprawozdań finansowych w podejmowaniu decyzji gospodarczych. Postępujący rozwój rynku kapitałowego w Polsce, tworzenie się coraz liczniejszych złożonych struktur gospodarczych w postaci grup kapitałowych wymusza na użytkownikach sprawozdań finansowych ciągłe poszerzanie i aktualizację wiedzy. Dlatego coraz większego znaczenia nabiera kwestia zestawiania zmian w skonsolidowanym kapitale własnym.

\section{Ocena wykorzystania zestawienia zmian w skonsolidowanym kapitale własnym - wyniki badań} Badania odbyły się trójetapowo.

- Pierwszy etap został przeprowadzony w okresie od grudnia 2004 r. do stycznia 2005 r. wśród podmiotów gospodarczych sporządzających skonsolidowane sprawozdania finansowe. 
Przedsiębiorstwa zostały dobrane na podstawie zamieszczonych w „Rzeczpospolitej” z 17.11.2004 r. wyników finansowych i wybranych wskaźników za I - III kwartał 2004 r. 198 spółek sporządzających skonsolidowane sprawozdania. Formularze ankiet zostały wypełnione przez dyrektorów ds. ekonomiczno-finansowych, głównych księgowych, specjalistów ds. finansów, kierowników działów finansowych, specjalistów ds. konsolidacji i kontroli, kierowników controlingu. Wysłano 198 formularzy, zwrot uzyskano od 69 przedsiębiorstw; pełną przydatność (poprawnie wypełnione) spełniło 65 ankiet (zwrotność 32,83\%).

- Drugi etap badań przeprowadzono w okresie styczeń - luty 2005 r. wśród biegłych rewidentów. Formularz ankiety wysłano do 300 osób wybranych metodą losową spośród 2034 podmiotów. Uzyskano 88 ankiet, pełną przydatność (poprawnie wypełnione) spełniło 88 ankiet (zwrotność 29,33\%).

- Trzeci etap trwał od kwietnia do sierpnia 2005 r. Analizę przypadku przeprowadzono w trzech grupach kapitałowych, prowadzących różną działalność gospodarczą i sporządzających skonsolidowane sprawozdania finansowe na podstawie krajowych i międzynarodowych regulacji prawnych.

Wybór respondentów próby badawczej wynikał z tematyki badań. Miały one na celu przedstawienie opinii na temat wartości informacyjnej zestawienia zmian w skonsolidowanym kapitale własnym osób odpowiedzialnych za sporządzanie tego elementu sprawozdania finansowego oraz osób zajmujących się kontrolą sprawozdawczości finansowej. Wszystkie grupy badanych mają niezbędną wiedzę, a często również kilkuletnie doświadczenie w przygotowywaniu i badaniu zmian w kapitale własnym.

Skonsolidowane sprawozdania finansowe dostarczają użytkownikom informacji o wynikach działalności oraz o sytuacji majątkowej i finansowej całej grupy kapitałowej. Jednym z elementów tego sprawozdania jest zestawienie zmian w skonsolidowanym kapitale własnym, które sporządzane jest przez większość jednostek dopiero od dwóch lat i przedstawia dane dotyczące dynamiki zmian w bieżącym i poprzednim okresie obrachunkowym w skonsolidowanym kapitale własnym w grupie kapitałowej. Zestawienie to stanowi wtórne źródło informacji finansowych; jednocześnie jest uzupełnieniem i rozwinięciem danych zaprezentowanych w skonsolidowanym bilansie.

Wyniki badań pozwalają na wskazanie najważniejszych użytkowników skonsolidowanych sprawozdań finansowych oraz obszarów, w których informacje zaprezentowane w zestawieniu zmian w skonsolidowanym kapitale są najczęściej wykorzystywane. Do najczęściej wymienianych użytkowników skonsolidowanych sprawozdań zalicza się:

- zarząd jednostki dominującej,

- banki udzielające kredytu jednostce dominującej,

- akcjonariuszy/udziałowców jednostki dominującej,

- potencjalnych inwestorów.

Na podstawie badań opinii pracowników księgowości ustalono najważniejszych użytkowników zestawienia zmian w skonsolidowanym kapitale własnym, szeregując ich w kolejności od 1 do 11 , według stopnia zapotrzebowania na informacje zawarte w sprawozdaniu finansowym. Wśród pracowników grup kapitałowych kolejność przedstawia tab. 1.

Również biegli rewidenci uporządkowali użytkowników według stopnia zapotrzebowania na informacje zawarte w skonsolidowanym kapitale własnym w kolejności przedstawionej w tab. 2 . 
Tab. 1. Najważniejsi użytkownicy zestawienia zmian w skonsolidowanym kapitale własnym w opinii pracowników służb finansowo-księgowych

\begin{tabular}{|l|c|}
\hline \multicolumn{1}{|c|}{ Użytkownik } & Średnia ważona \\
\hline Menedżerowie zarządzający jednostkami wchodzącymi w skład grupy & 4,52 \\
\hline Kontrahenci jednostki dominującej & 4,44 \\
\hline Zarząd jednostki dominującej & 3,87 \\
\hline Banki udzielające kredytu jednostce dominującej & 3,46 \\
\hline Banki udzielające kredytu jednostce podporządkowanej & 3,24 \\
\hline Kontrahenci grupy kapitałowej & 2,80 \\
\hline Udziałowcy/akcjonariusze jednostki dominującej & 2,58 \\
\hline Udziałowcy/akcjonariusze wchodzący w skład grupy & 2,25 \\
\hline Potencjalni inwestorzy & 2,21 \\
\hline Zarządy poszczególnych spółek wchodzących w skład grupy & 2,04 \\
\hline Menedżerowie zarządzający grupą & 1,94 \\
\hline
\end{tabular}

Źródło: opracowanie autorki na podstawie wyników badań opinii pracowników księgowości

Tab. 2. Najważniejsi użytkownicy zestawienia zmian w skonsolidowanym kapitale własnym w opinii biegłych rewidentów

\begin{tabular}{|l|c|}
\hline \multicolumn{1}{|c|}{ Użytkownik } & Średnia ważona \\
\hline Menedżerowie zarządzający grupą kapitałową & 3,98 \\
\hline Potencjalni inwestorzy & 3,79 \\
\hline Zarządy poszczególnych spółek wchodzących w skład grupy & 3,57 \\
\hline Udziałowcy/akcjonariusze jednostki dominującej & 3,41 \\
\hline Banki udzielające kredytu jednostce podporządkowanej & 3,05 \\
\hline Zarząd jednostki dominującej & 2,78 \\
\hline Banki udzielające kredytu jednostce dominującej & 2,70 \\
\hline Udziałowcy/akcjonariusze wchodzący w skład grupy & 2,31 \\
\hline Menedżerowie zarządzający jednostkami wchodzącymi w skład grupy & 2,00 \\
\hline Społeczeństwo lokalne & 2,00 \\
\hline Kontrahenci grupy kapitałowej & 1,79 \\
\hline Urzędy skarbowe & 1,60 \\
\hline Kontrahenci jednostki dominującej & 1,00 \\
\hline
\end{tabular}

Źródło: opracowanie autorki na podstawie wyników badań opinii biegłych rewidentów

Uwzględniając stopień zapotrzebowania na informacje zawarte w skonsolidowanym sprawozdaniu, każda grupa badanych wskazała innych użytkowników, co przedstawiono w tab. 3 .

Zdaniem pracowników służb finansowo-księgowych, najważniejszymi użytkownikami informacji zawartych w skonsolidowanym sprawozdaniu są menedżerowie zarządzający jednostkami wchodzącymi w skład grupy, kontrahenci i zarząd jednostki dominującej. Inna klasyfikacja została przedstawiona przez biegłych rewidentów, którzy - poza grupą kierowniczą jednostki dominującej 
Tab. 3. Najważniejsi użytkownicy zestawienia zmian w skonsolidowanym kapitale własnym w opinii pracowników służb finansowo-księgowych i biegłych rewidentów

\begin{tabular}{|c|c|}
\hline \multicolumn{2}{|c|}{ Najważniejsi użytkownicy w ocenie } \\
\hline pracowników służb finansowo-księgowych & biegłych rewidentów \\
\hline $\begin{array}{l}\text { Menedżerowie zarządzający jednostkami } \\
\text { wchodzącymi w skład grupy }\end{array}$ & Menedżerowie jednostki dominującej \\
\hline Kontrahenci jednostki dominującej & Potencjalni inwestorzy \\
\hline Zarząd jednostki dominującej & Udziałowcy/akcjonariusze jednostki dominującej \\
\hline
\end{tabular}

Źródło: opracowanie autorki na podstawie wyników badań opinii pracowników księgowości i biegłych rewidentów

- głównie skupili się na właścicielach wnoszących kapitał do jednostki oraz potencjalnych właścicielach, którzy są na etapie podejmowania decyzji inwestycyjnych (kapitałowych).

W pracy badawczej ustalono również kolejność najważniejszych obszarów, w których wykorzystywane są informacje zawarte w zestawieniu zmian w skonsolidowanym kapitale własnym. Wyniki badań opinii przedstawia tab. 4 .

Tab. 4. Najważniejsze obszary wykorzystania informacji zawartych w zestawieniu zmian w skonsolidowanym kapitale własnym w opinii pracowników służb finansowo-księgowych

\begin{tabular}{|l|c|}
\hline \multicolumn{1}{|c|}{ Treśćc } & Średnia ważona \\
\hline Określenie bieżącej wartości firmy & 3,86 \\
\hline Analiza dynamika zmian aktywów netto & 3,65 \\
\hline Analiza sytuacji majątkowej i zdolności kredytowej & 3,62 \\
\hline Wpływ wyniku finansowego na wartość kapitałów własnych & 3,32 \\
\hline Aktualizacja wyceny składników majątkowych & 3,09 \\
\hline Polityka wypłaty dywidend i jej wpływ na wartość firmy & 2,96 \\
\hline Podjęcie decyzji strategicznych przez potencjalnych inwestorów & 2,67 \\
\hline $\begin{array}{l}\text { Analiza wielkości uzyskanych przychodów i poniesionych kosztów } \\
\text { wpływających bezpośrednio na kapitał własny }\end{array}$ & 2,50 \\
\hline Ustalenie bieżącej wartości posiadanych udziałów & 2,29 \\
\hline Budowa strategii rozwoju przez zarząd spółki dominującej & 1,47 \\
\hline
\end{tabular}

Źródło: opracowanie autorki na podstawie wyników badań opinii pracowników księgowości

Najczęściej wskazywany przez respondentów jest obszar dotyczący wpływu wyniku finansowego na wartość kapitałów własnych. Jednak za najważniejszy należy uznać obszar dotyczący możliwości wykorzystania informacji służącej określeniu bieżącej wartości firmy. Wyznacznikiem tego obszaru była najwyższa średnia ważona, która wynosi 3,86. Pozostałe obszary, w których równie ważnych informacji dostarcza zestawienie zmian w skonsolidowanym kapitale własnym, to:

- analiza dynamiki zmian aktywów netto,

- analiza sytuacji majątkowej i zdolności kredytowej,

- wpływ wyniku finansowego na wartość kapitałów własnych,

- aktualizacja wyceny składników majątkowych. 
Wymienione wyżej obszary w sposób pośredni dostarczają użytkownikom informacji o zmianach w aktywach netto, a przede wszystkim zaspokajają potrzeby informacyjne niezbędne do analizy wstępnej dla:

- akcjonariuszy, których interesuje wartość osiąniętego zysku, opłacalność zaangażowanego kapitału i wysokość dywidend,

- wierzycieli zainteresowanych oceną płynności finansowej przedsiębiorstwa i jego wypłacalnością,

- banków koncentrujących swoją uwagę przede wszystkim na udzielaniu kredytów.

Wskazane przez respondentów obszary stanowią cenne źródło informacji o ewolucji prawa własności, sygnalizując jednocześnie o preferencjach inwestycyjnych właścicieli jednostki gospodarczej.

Zdaniem biegłych rewidentów, za najważniejszy należy uznać obszar dotyczący możliwości wykorzystania informacji do określenia bieżącej wartości firmy (tab. 5). Jego wyznacznikiem była najwyższa średnia ważona (4,03). Wykorzystanie informacji w zakresie określenia wpływu wyniku finansowego na wartość kapitałów własnych stanowi drugi obszar, w którym najczęściej wykorzystuje się dane zawarte w zestawieniu.

Kolejne obszary wskazane przez biegłych rewidentów to:

- wpływ wyniku finansowego na wartość kapitałów własnych,

- analiza wielkości uzyskanych przychodów i poniesionych kosztów wpływających bezpośrednio na wysokość kapitału własnego,

- ustalenie bieżącej wartości posiadanych akcji/udziałów,

- polityka wypłaty dywidendy i jej wpływ na wartość firmy.

Tab. 5. Najważniejsze obszary wykorzystania informacji zawartych w zestawieniu zmian w skonsolidowanym kapitale własnym w opinii biegłych rewidentów

\begin{tabular}{|l|c|}
\hline \multicolumn{1}{|c|}{ Treść } & Średnia ważona \\
\hline Określenie bieżącej wartości firmy & 4,03 \\
\hline Wpływ wyniku finansowego na wartość kapitałów własnych & 3,59 \\
\hline $\begin{array}{l}\text { Analiza wielkości uzyskanych przychodów i poniesionych } \\
\text { kosztów wpływających bezpośrednio na kapitał własny }\end{array}$ & 3,50 \\
\hline Ustalenie bieżącej wartości posiadanych akcji/udziałów & 3,29 \\
\hline Polityka wypłaty dywidend i jej wpływ na wartość firmy & 3,09 \\
\hline Analiza dynamika zmian aktywów netto & 2,86 \\
\hline Analiza sytuacji majątkowej i zdolności kredytowej & 2,81, \\
\hline Aktualizacja wyceny składników majątkowych & 2,57 \\
\hline Budowa strategii rozwoju przez zarząd spółki dominującej & 2,16 \\
\hline Podjęcie decyzji strategicznych przez potencjalnych inwestorów & 2,09 \\
\hline
\end{tabular}

Źródło: opracowanie autorki na podstawie wyników badań opinii biegłych rewidentów

Aby wskazać obszary, w których wykorzystywane są informacje zawarte w zestawieniu zmian w skonsolidowanym kapitale własnym, należy dokonać podziału ze względu na grupę badanych (tab. 6). 
Tab. 6. Najważniejsze obszary wykorzystania informacji zawartych w zestawieniu zmian w skonsolidowanym kapitale własnym w opinii pracowników służb finansowo-księgowych i biegłych rewidentów

\begin{tabular}{|l|l|}
\hline \multicolumn{2}{|c|}{ Najważniejsze obszary w ocenie } \\
\hline \multicolumn{1}{|c|}{ pracowników służb finansowo-księgowych } & \multicolumn{1}{c|}{ biegłych rewidentów } \\
\hline Określenie bieżącej wartości firmy & Określenie bieżącej wartości firmy \\
\hline Analiza dynamiki zmian aktywów netto & $\begin{array}{l}\text { Wpływ wyniku finansowego na wartość } \\
\text { kapitałów własnych }\end{array}$ \\
\hline Analiza sytuacji majątkowej i zdolności kredytowej & $\begin{array}{l}\text { Analiza wielkości uzyskanych przychodów } \\
\text { i poniesionych kosztów wpływających } \\
\text { bezpośrednio na kapitał własny }\end{array}$ \\
\hline
\end{tabular}

Źródło: opracowanie autorki na podstawie wyników badań opinii pracowników księgowości i biegłych rewidentów

Wskazane przez respondentów obszary pozwalają na ocenę zmian zachodzących w stanie majątkowym jednostki, przede wszystkim tej części majątku, która bezterminowo pozostaje do dyspozycji jednostki i stanowi jej własność. Na szczególną uwagę zasługuje uznanie przez respondentów określenia bieżącej wartości firmy za najważniejszy obszar wykorzystywania informacji o zmianach zachodzących w skonsolidowanym kapitale. Oznacza to, że podejmowanie decyzji inwestycyjnych oraz opracowywanie strategii działania jest tym łatwiejsze, im dokładniej znana jest bieżąca wartość majątku.

Jednostka dominująca posiada udziały w poszczególnych podmiotach wchodzących w skład grupy kapitałowej i chociaż na co dzień bezpośrednio nimi nie dysponuje, to jednak wpływa na politykę jednostek zależnych, współzależnych i stowarzyszonych. Dlatego do prawidłowej oceny sytuacji finansowej-zdaniem użytkowników - bardziej przydatne są szczegółowe informacje dotyczące zestawienia zmian w kapitałach własnych jednostki dominującej niż zestawienia zmian w jednostek podległych.

\section{Podsumowanie}

Informacje zawarte $\mathrm{w}$ zestawieniu zmian w skonsolidowanym kapitale własnym ułatwiają podejmowanie decyzji, a szczegółowa analiza tytułów zmian pozwala na określenie zyskowności kapitału i określenie bieżącej wartości akcji/udziału. Chociaż użytkownicy zestawienia dostrzegają korzyści wynikające z jego analizy, to jednak występujące różnego typu bariery nie pozwalają w pełni wykorzystywać informacji o skonsolidowanym kapitale. Krótki okres jego sporządzania nie pozwala użytkownikom na uzyskanie wystarczającej i ugruntowanej wiedzy.

Można przyjąć, że zestawienie zmian w skonsolidowanym kapitale własnym dostarcza szerokiej grupie użytkowników różnorodnych informacji, które bezpośrednio lub pośrednio wpływają na decyzje podejmowane przez adresatów sprawozdań. Wprowadzenie do rachunkowości zestawienia zmian w kapitałach własnych jest wynikiem globalizacji gospodarki i harmonizacji rachunkowości na skalę międzynarodową. Zestawienie to dostarcza nowych informacji, a zarazem stanowi rozszerzenie danych zawartych w bilansie i rachunku zysków i strat. Jednak nie dla wszystkich użytkowników wewnętrznych i zewnętrznych, ma ono taką samą wartość użytkową, wykorzystywaną na jednakowym poziomie. Uzyskane z badań informacje mogą stanowić pewne wskazówki odnośnie do wykorzystania zestawienia zmian w skonsolidowanym kapitale własnym przez wybrane grupy użytkowników.

Na podstawie przedstawionych analiz przypadków grup kapitałowych: Apator S.A., Elektrociepłownia Toruń S.A. i Przedsiębiorstwo Handlowe Koekstra B.V. można wyciągnąć wniosek, 
że informacje zawarte w zestawieniach zmian w skonsolidowanych kapitałach własnych są przydatne przede wszystkim inwestorom, którzy śledzą zmiany w kapitałach, gdyż na ich podstawie właściciele mogą określić, jaka część majątku przypada na jedną akcję. Ponadto informacje dotyczące zmian w kapitale zapasowym pozwalają na określenie wielkości zatrzymanego zysku. Niestety, inwestorzy mają tu utrudnione zadanie, ponieważ w zestawieniu nie znajdą informacji o liczbie wyemitowanych akcji i o ich wartości nominalnej. Uzupełnienie zestawienia zmian w skonsolidowanym kapitale własnym o te informacje ułatwiłoby w znacznej mierze analizę zyskowności zainwestowanego kapitału i ograniczyło czas poświęcony na poszukiwanie tych informacji.

Zestawienie zmian w skonsolidowanym kapitale własnym stanowi jedynie uzupełnienie i poszerzenie informacji zawartych w bilansie i informacji dodatkowej, dlatego dla wielu użytkowników zarówno wewnętrznych, jak i zewnętrznych jest to nie w pełni wykorzystane źródło informacji.

\section{Statements of Changes in a Consolidated Ownership Capital}

Aim of the work is to present methods of developing and titles to implement changes in the ownership capitals for various legal entities. It covers the contents and the form of presentation of the statement of changes in consolidated ownership capital (with regard to domestic and foreign legal regulations). The work emphasize informational value of the statement for groups of users (internal and external) as well as its usability. Specific rules concerning a development of the financial statements and methods of their consolidation are presented. The work focuses on functions and relations in financial groups. 